\title{
SOEP
}

SOEPpapers

SOEPpapers
on Multidisciplinary Panel Data Research

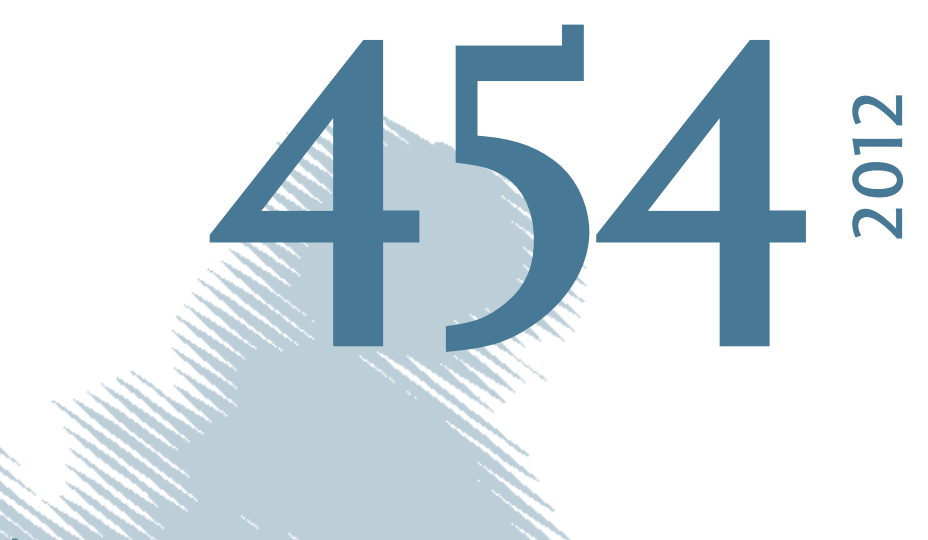

(

\section{Temporary agency work in the SOEP: Coping with data quality problems}




\section{SOEPpapers on Multidisciplinary Panel Data Research}

at DIW Berlin

This series presents research findings based either directly on data from the German SocioEconomic Panel Study (SOEP) or using SOEP data as part of an internationally comparable data set (e.g. CNEF, ECHP, LIS, LWS, CHER/PACO). SOEP is a truly multidisciplinary household panel study covering a wide range of social and behavioral sciences: economics, sociology, psychology, survey methodology, econometrics and applied statistics, educational science, political science, public health, behavioral genetics, demography, geography, and sport science.

The decision to publish a submission in SOEPpapers is made by a board of editors chosen by the DIW Berlin to represent the wide range of disciplines covered by SOEP. There is no external referee process and papers are either accepted or rejected without revision. Papers appear in this series as works in progress and may also appear elsewhere. They often represent preliminary studies and are circulated to encourage discussion. Citation of such a paper should account for its provisional character. A revised version may be requested from the author directly.

Any opinions expressed in this series are those of the author(s) and not those of DIW Berlin. Research disseminated by DIW Berlin may include views on public policy issues, but the institute itself takes no institutional policy positions.

The SOEPpapers are available at

http://www.diw.de/soeppapers

\section{Editors:}

Jürgen Schupp (Sociology, Vice Dean DIW Graduate Center)

Gert G. Wagner (Social Sciences)

Conchita D'Ambrosio (Public Economics)

Denis Gerstorf (Psychology, DIW Research Professor)

Elke Holst (Gender Studies)

Frauke Kreuter (Survey Methodology, DIW Research Professor)

Martin Kroh (Political Science and Survey Methodology)

Frieder R. Lang (Psychology, DIW Research Professor)

Henning Lohmann (Sociology, DIW Research Professor)

Jörg-Peter Schräpler (Survey Methodology, DIW Research Professor)

Thomas Siedler (Empirical Economics)

C. Katharina Spieß (Empirical Economics and Educational Science)

ISSN: 1864-6689 (online)

German Socio-Economic Panel Study (SOEP)

DIW Berlin

Mohrenstrasse 58

10117 Berlin, Germany

Contact: Uta Rahmann | soeppapers@diw.de 


\title{
Temporary agency work in the SOEP: Coping with data quality problems
}

\author{
Holger Schäfer \\ Institut der deutschen Wirtschaft Köln \\ Georgenstr. 22 \\ 10117 Berlin \\ Mail: schaefer.holger@iwkoeln.de
}

\begin{abstract}
In principle, the SOEP is a highly adequate data source for analyzing the socioeconomic background of temporary agency workers. In this paper, it's argued that on second glance, the SOEP's temp worker variable shows severe problems with data quality. An easyto-use adjustment procedure is proposed that alleviates the problem, but is not an encompassing solution. Therefore, it is concluded that in the long term, the questionnaire needs to be improved.
\end{abstract}

JEL: C83, J53

Keywords: temporary agency work, panel surveys 
Temporary agency work remains in the focus of the debate about the role of atypical work in Germany. Following its de-regulation in the context of the Hartz labour market reforms in 2003, employment in temp agency work more than doubled from 330,000 in 2003 to 780,000 in 2010 (Statistik der Bundesagentur für Arbeit 2011). The success of this employment form prompted an ongoing debate about re-regulation policies, such as a more strict application of the equal-pay principle. Those who call for more regulation justify their demand with the assumption that temp agency workers are more prone to precariousness (e.g. Adamy 2010). While the definition of precariousness differs among authors, it's apparent that testing the assumption empirically requires comprehensive data.

Information about temp agency workers is available in several data sources. The Federal Statistical Office's Mikrozensus includes information about temp agency work, but does not ask for gross wages. This problem severely reduces the analytical possibilities. Data based on the employment register includes comprehensive, even longitudinal job and wage information, but almost no data on the socio-economic background such as household type and income. Moreover, since information on working time and productivity-related personal items are limited, it's difficult to estimate an econometric model and, particularly, the effects of the employment form on wages. Finally, these data sources cannot distinguish between temp workers and the temp agency's regular staff. The Arbeitnehmerüberlassungsstatistik, which is a data set that is collected from the mandatory temp agency firm's reports to the federal employment agency, is the main official source about employment numbers in the temp agency sector, but holds little information about personal characteristics of the temp workers. The same applies to various establishment surveys.

The SOEP seems to remedy almost all of the shortcomings mentioned above. It allows longitudinal analyses, the combination of personal and household information and provides a wide array of socio-economic variables. Since 2001, respondents are asked whether their current job is a temp agency job. These characteristics stimulated already some empirical research on the link between temp agency work and incidence of precariousness using the SOEP (Brehmer/Seifert 2008; Dütsch 2011; SVR 2011, p. 294 f.). However, the SOEP has some idiosyncratic problems with temporary agency work. In this paper, it's argued that the temp agency work variable in the SOEP shows severe problems with respect to data quality. Therefore, the treatment of this variable is not easy when using it for research or even policy recommendations about temp agency work.

\section{Development of temp agency work since 2001 in the SOEP}

Since 2001, the person questionnaire in the SOEP asks for temp agency work. In 2001 (R wave), question no. 37 asks "Since when have you been working for your current employer?", followed by the question no. 38 "Is this an employment agency specializing in temporary help?". In fact, the question in the German version of the questionnaire is a bit more compact ("Handelt es sich um eine Zeitarbeitsfirma?"). Thus, the temp agency question is very closely 
related to the current job characteristics. This could be a problem for respondents in temp agency work, because they might not differentiate between their original employer, which is the temp agency, and the company, in which they are working currently. If they answered the previous questions with respect to the temp agency firm's customer - i.e. the place where they are working - then the question about the employment agency might be answered with "no", because the temp agency as the genuine employer is not seen as the "current job". This problem might lead to an underestimation of temp agency work.

In addition, there are possibly more problems with the temp agency question. Disaggregating temp agency workers by employment form shows that some respondents apparently have difficulties to understand the question: Out of 172 temp workers in the 2001 sample, 3 reported to be self-employed which excludes the possibility to be in temp agency work - except the respondents owned a temp agency firm. However, this is highly unlikely given the branches they reported to work in: industry, retail and communication. More likely is that they somehow misunderstood the question. The same is true for the 5 individuals, who were in an apprenticeship and reported to work in a temp agency firm. This is not impossible. Temp agency firms have regular staff and apprentices. But again, the branches they reported to work in (broadcast, construction, retail and health services) make it more likely that they misunderstood the question.

But even if we exclude the self-employed and apprentices from the analysis, the numbers don't add up. Cross-sectional weighting with the \$PHRF weighting variable results in 520,000 temp workers in 2001. Calculating a comparative figure from the official register data ${ }^{1}$ shows that in this year the number of temp workers didn't exceed 340,000 - a difference of about 50 percent. The SOEP vastly overestimated the number of temp agency workers. This is a surprising result, since we might expect higher numbers in the official data than in the SOEP.

Things became even worse when the question about temp agency work was re-phrased in the 2003 questionnaire. Since then, the question that follows after the question for tenure ("Since when have you been working for your current employer?") changes in "Is this work temporary or on a contractual basis?". Again, in the German questionnaire the phrasing is somewhat different ("Handelt es sich um ein Zeitarbeits- bzw. Leiharbeitsverhältnis?"). As a result of this adjustment, the weighted number of temp workers in the SOEP rose from 500,000 in the year 2002 to over one million in 2003 while in the official data, the number almost didn't change at all (figure 1). This is not a question of weighting, as the line chart for the unweighted number of temp agency workers shows. In addition, the share of temp agency workers of total employment (not counting apprentices) is much higher in the SOEP (3.4\%) than in official data $(1.0 \%)$.

Figure 1 demonstrates that there's something wrong with the provision of information about temp agency work in the SOEP. First, the number of temp agency workers in the SOEP is much higher than in official register data - in some years more than three times higher. Se-

\footnotetext{
${ }^{1}$ To compare SOEP and official data, the share of SOEP interviews with temp workers conducted in a particular month is calculated and multiplied with the official number of temp workers in this month. The sum over all months in a given year is then used as the official comparative figure.
} 
cond, the SOEP data fails to reflect the basic trends in temp agency employment, i.e. the continuous rise up to 2008 followed by a sudden drop in the year 2009 as a result of the economic crisis. Instead, the SOEP reports a sharp rise in temp agency employment in 2003, but this was most likely caused by the revision of the questionnaire. In order to find an explanation for the large over-estimation in the SOEP, it is therefore useful to look at changes between 2002 and 2003.

Figure 1: Number of temporary agency workers

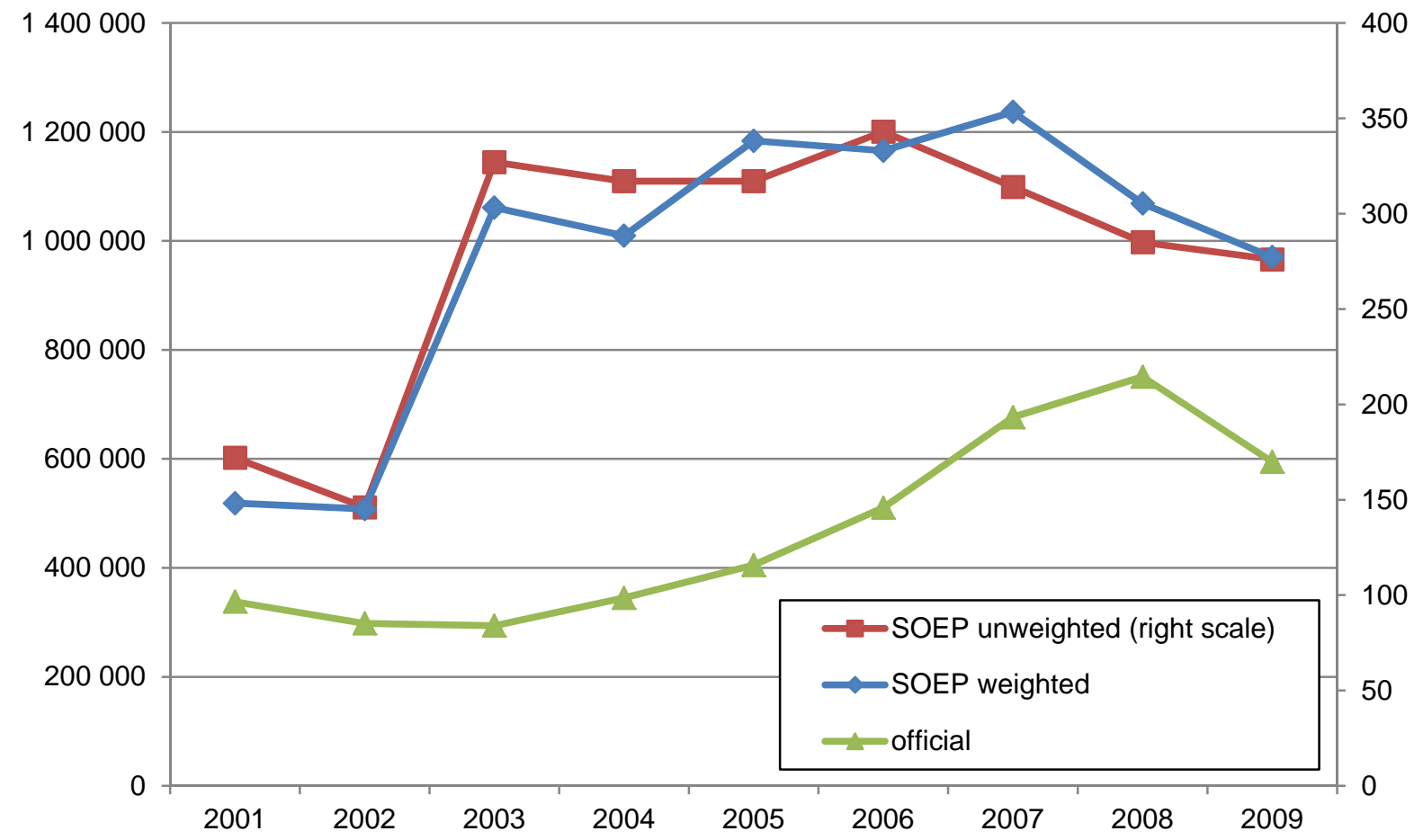

Excluding self-employed and apprentices

Source: SOEP, Statistik der Bundesagentur für Arbeit, own calculations

\section{$3 \quad$ Assessing the gap}

The difference between the SOEP and the official statistic about temp agency work is of such dimension, that it seems unlikely that it is caused by weighting problems or a too small sample size for this sub-population. Instead, it seems more likely that respondents systematically misinterpret the question.

Obviously, one might assume that the question is misunderstood as a question about fixedterm contracts - even though the fixed-term contract question is asked right after the temp agency question in the person questionnaire. This assumption is supported by the unusually high ratio of fixed-term workers amongst the temp agency workers in the SOEP, which exceeded 50 percent in the year 2006 (figure 2). If we compare this to the Mikrozensus, this share is only 31 percent (Puch 2008). Illustrative is the SOEP's sharp increase of the fixedterm share in the year 2003, when the question in the questionnaire was adjusted. In this year, the number of weighted fixed-term workers, who classified themselves to be temp agency 
workers, rose from 120,000 to 420,000 . At the same time, the weighted number of fixed-term workers outside the temp agency sector declined from 2.10 million to 1.92 million.

Figure 2: Share of fixed-term contracts

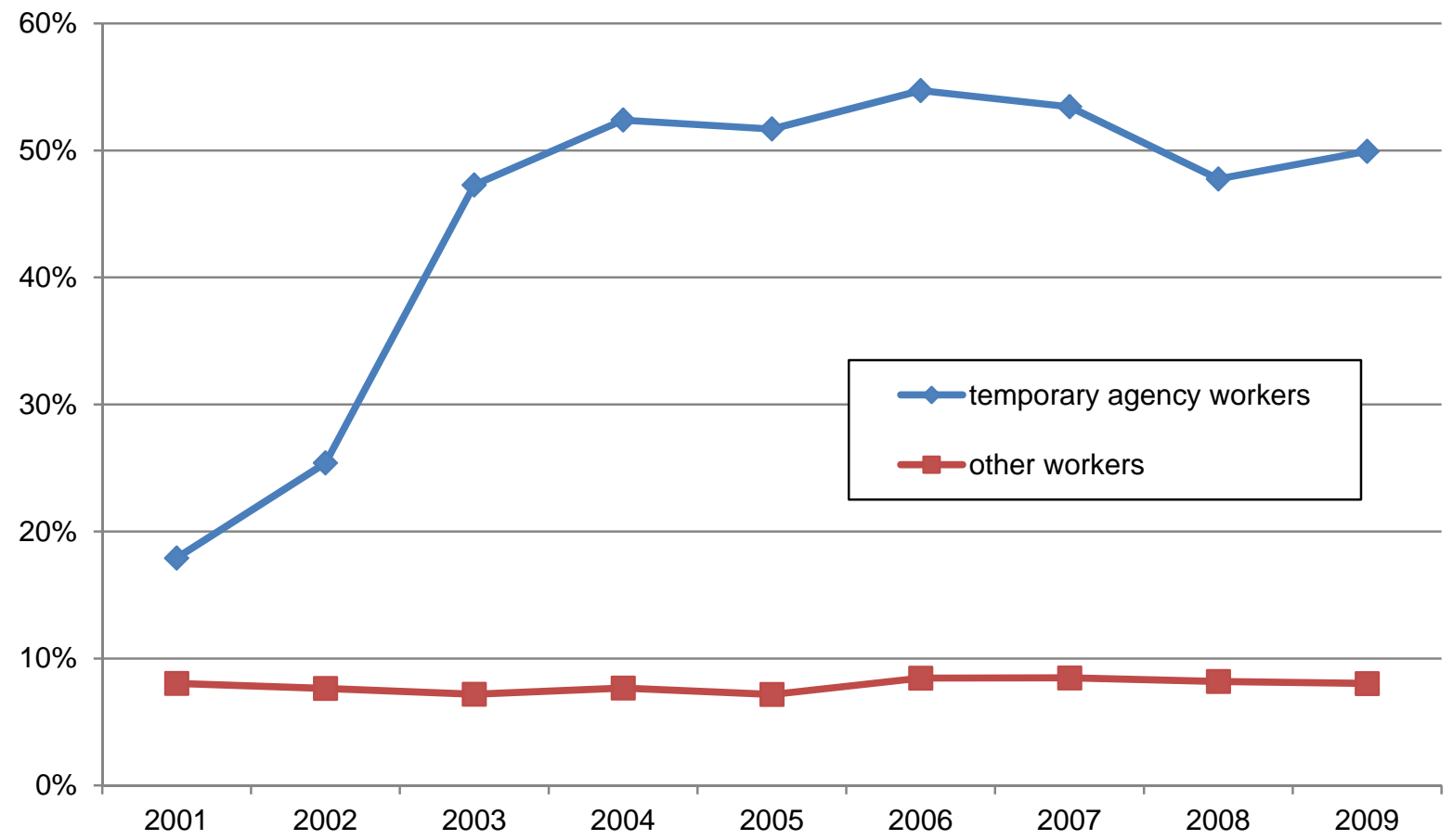

Excluding self-employed and apprentices

Source: SOEP, own calculations

A characteristic feature of the SOEP is that it allows longitudinal analysis. Thus, it is possible to investigate the employment history of all these new temp agency workers in the year 2003. Defining the temp agency workers in 2003 as a new sub-sample, we find that only a small fraction of them were already in temp agency work the year before (34 of 327, not counting self-employed and apprentices ${ }^{2}$ ). More than half of the 2003 temp workers (183) were not in agency work the year before, but in some other form of employment. About one third (110) was either not in the labor force or not in the sample. Respondents being most suspicious of misunderstanding the temp agency question are the 2003 agency workers who were already in (non-temp-agency) employment in the year 2002. Out of these 183 respondents, 169 were either in full-time-employment, part-time-employment or in a mini-job in 2002. The remaining respondents came from self-employment or apprenticeships. Out of these 169, only 48 reported a job change. ${ }^{3}$ The majority of 119 respondents reported no job change, but nevertheless claimed to be not in temp agency work in 2002 and to be in agency work in 2003 . These apparently inconsistent responses accounted for almost two thirds of the increase in the SOEP's temp agency employment between 2002 and 2003.

However, these 119 inconsistent answers are not responsible for the sudden increase of fixedterm contracts amongst temp agency workers. Only 35 of the 119 cases had a fixed term contract in 2003. And the majority of these (27) were already in fixed-term employment the year

\footnotetext{
${ }^{2}$ Only respondents with valid information on employment status

${ }^{3}$ Measured using the generated JOBCH\$ variable
} 
before. Most of the fixed-term temp agency workers in 2003 were either not employed in 2002 or they were not found in the sample (63 of 132). Only 21 were employed in an openended contract. Therefore, the increase in fixed-term temp agency employment was caused predominantly by respondents, who didn't answer the temp agency question in the previous year.

There are two more explanations for this phenomenon: On the one hand, those respondents are - in fact - entering the temp agency sector with a fixed-term contract. This is not entirely unreasonable. It is known from other research that the share of fixed-term contracts is almost 50 percent amongst new entries into employment (Hohendanner 2010). Moreover, in the year 2003 many regulations in the temporary agency work sector were abolished. In particular, it became possible to limit the duration of employment contracts according to the length of an assignment in a customer firm. On the other hand, this assumption does not explain the simultaneous expansion of temp agency work far beyond the levels reported by official data sources. An alternative or perhaps complementary explanation is, therefore, that new labor market entries were not able to differentiate between temp agency work and fixed-term contracts or had difficulties to understand the concept of temp agency work.

Following the thesis that respondents fail to understand the question about temp agency work, we may find some supportive evidence if those who claim to be temp agency workers show some specific characteristics with respect to interview method, sub-sample or migration background. The underlying assumption would be that the alleged temp workers are panelists, who are new to the questionnaire, have difficulties to understand the questions and/or have a problem with the German language. Table 1 shows that the sub-sample offers no explanation for the apparently inconsistent responses of some agency workers. The distribution is roughly the same for agency workers, agency workers with inconsistent responses and non-agency workers.

However, with respect to the interview method, there are notable differences. Agency workers with inconsistent responses have less often conducted oral or CAPI interviews in comparison with agency workers in general and with non-agency workers. Instead, they have more often filled out the questionnaires on their own. Therefore, there's an increased probability that they didn't understand the question about agency work and had no interviewer support to ask for clarification. In addition, inconsistent respondents more often had a migration background than agency workers in general. To a lesser degree, these results hold also for agency workers, who were either not employed or not in the sample in the previous year. 


\begin{tabular}{|c|c|c|c|c|c|}
\hline & $\begin{array}{l}\text { agency } \\
\text { workers }\end{array}$ & $\begin{array}{l}\text { agency } \\
\text { workers, } \\
\text { elsewhere } \\
\text { employed } \\
\text { in } 2002\end{array}$ & $\begin{array}{l}\text { of which: } \\
\text { didn't report } \\
\text { job change } \\
\text { (i.e. incon- } \\
\text { sistent re- } \\
\text { sponse) }\end{array}$ & $\begin{array}{l}\text { agency } \\
\text { workers, } \\
\text { not em- } \\
\text { ployed or } \\
\text { not in } \\
\text { sample in } \\
2002\end{array}$ & $\begin{array}{l}\text { non- } \\
\text { agency } \\
\text { workers }\end{array}$ \\
\hline \multicolumn{6}{|l|}{ sample: } \\
\hline A Germans (West) & $21 \%$ & $24 \%$ & $22 \%$ & $19 \%$ & $25 \%$ \\
\hline B Foreigners (West) & $8 \%$ & $8 \%$ & $8 \%$ & $7 \%$ & $7 \%$ \\
\hline C Germans (East) & $18 \%$ & $15 \%$ & $15 \%$ & $19 \%$ & $15 \%$ \\
\hline D Migrants (West) 1984-93 & $6 \%$ & $5 \%$ & $4 \%$ & $7 \%$ & $4 \%$ \\
\hline E Supplement 1998 & $3 \%$ & $4 \%$ & $3 \%$ & $2 \%$ & $5 \%$ \\
\hline F Supplement 2000 & $35 \%$ & $34 \%$ & $36 \%$ & $38 \%$ & $34 \%$ \\
\hline G High Income Sample 2002 & $9 \%$ & $11 \%$ & $11 \%$ & $7 \%$ & $10 \%$ \\
\hline \multicolumn{6}{|l|}{ interview method: } \\
\hline Oral interview & $18 \%$ & $18 \%$ & $16 \%$ & $18 \%$ & $22 \%$ \\
\hline $\begin{array}{l}\text { Written interview, with inter- } \\
\text { viewer present }\end{array}$ & $4 \%$ & $7 \%$ & $8 \%$ & $2 \%$ & $4 \%$ \\
\hline $\begin{array}{l}\text { Written interview, without } \\
\text { interviewer present }\end{array}$ & $39 \%$ & $37 \%$ & $39 \%$ & $42 \%$ & $31 \%$ \\
\hline partly oral, partly written & $5 \%$ & $4 \%$ & $5 \%$ & $6 \%$ & $4 \%$ \\
\hline written interview (mail) & $17 \%$ & $20 \%$ & $22 \%$ & $19 \%$ & $13 \%$ \\
\hline CAPI & $16 \%$ & $14 \%$ & $11 \%$ & $15 \%$ & $26 \%$ \\
\hline migration background & $24 \%$ & $21 \%$ & $20 \%$ & $23 \%$ & $16 \%$ \\
\hline
\end{tabular}

Source: SOEP, own calculations

\section{$4 \quad$ Workaround and long-term solution}

The multiple problems with the temp agency work variable complicate an encompassing solution. Concerning the existing data, it cannot be concluded whether a respondent misconceived the agency question or even failed to understand the concept of agency work. However, it is obvious that a sizable proportion of respondents gave inconsistent answers. A minimal adjustment would be to exclude at least those cases from the analysis. Therefore, the proposed method would be to change the raw SOEP temporary agency work variable by

- excluding self-employed and apprentices,

- excluding agency workers, who didn't report a job change, but were not in temporary agency work the year(s) before.

This adjustment procedure results in a number of agency workers that is somewhat more close to the official figure than the original SOEP variable (see green line in figure 3). But there are still notable differences to the official figure which may not be attributed to the higher volatility of estimates based on small sample sizes. In addition, the unreasonably high share of fixed-term contracts amongst temp agency workers is even a little higher when the proposed adjustment is used. 
Figure 3: Temporary agency workers

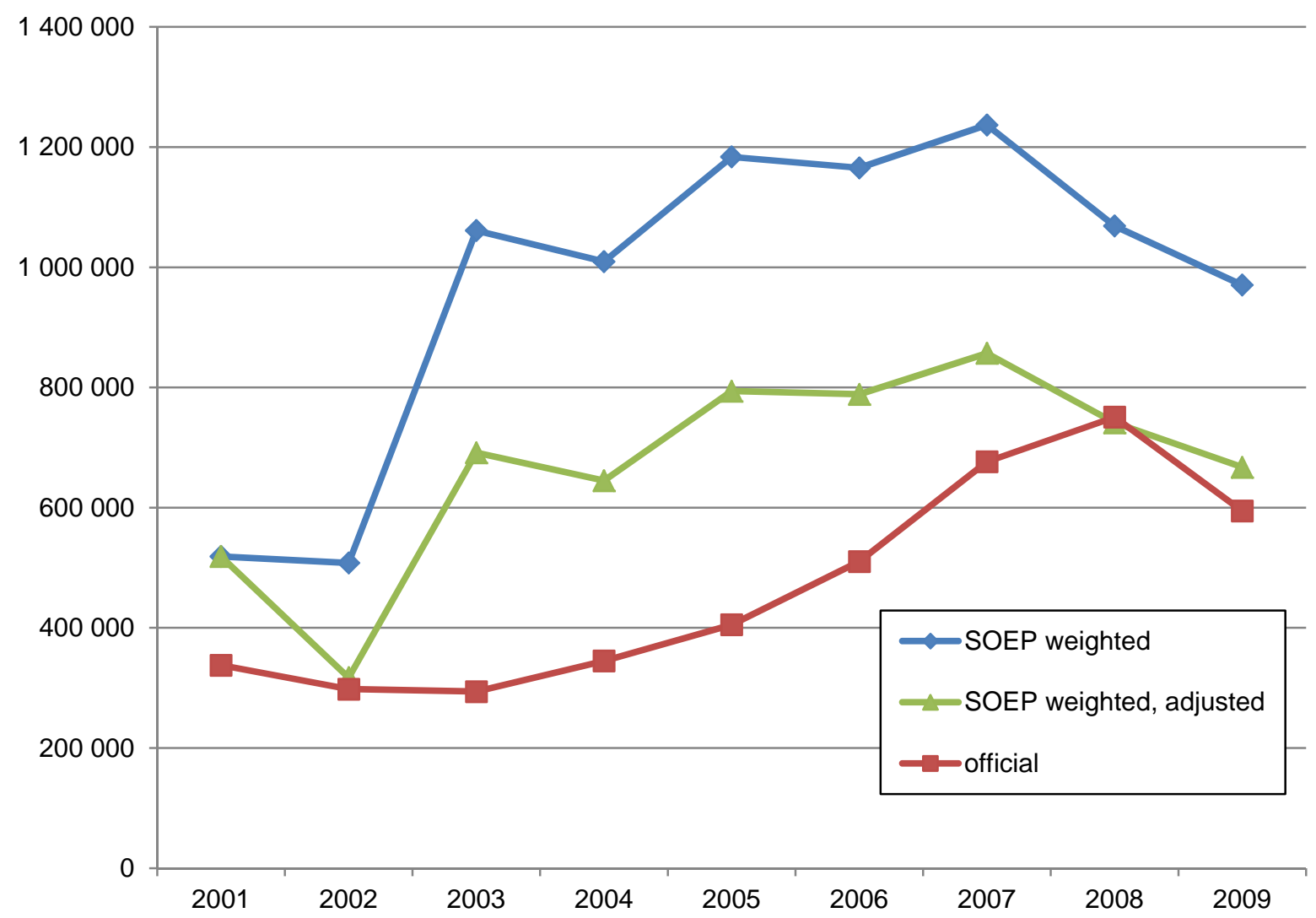

Excluding self-employed and apprentices

Source: SOEP, own calculations

In the long-term, it seems to be necessary to rephrase the questionnaire to improve the temp agency work variable's data quality. First, the respondent's confusion about temp agency work and fixed-term contracts might be reduced if the term "Zeitarbeit" is avoided or at least briefly explained. While "Zeitarbeit" is probably a common term for temp agency work amongst labour market analysts, it is less common amongst the general public. "Leiharbeit" is sometimes conceived as a derogatory term for temp agency work, but in this case, it may help to clarify the question. In addition, the question could be complemented by a small explanatory text about the concept of agency work, which may also support interviewers in field work. Second, confusion could be avoided if the order of the questions is reversed, i.e. if it is first asked about a fixed-term contract and afterwards about temp agency work, stating expressively that these are different things. Third, it seems advisable to monitor the effects of the proposed alterations of the questionnaire closely by comparing SOEP estimates to official data.

\section{$5 \quad$ Conclusions}

In principle, the SOEP is a highly adequate data source when analyzing the socio-economic background of temporary agency workers. At a second glance, however, severe problems with data quality become apparent. First, the SOEP's number of temp workers is much higher than in official data. Second, the SOEP data reflect the 2003 change in the questionnaire, but did not display the official data's trend. Third, the SOEP's temp workers in 2003 show an unrea- 
sonable high share of fixed-term contracts. To sum up, these results suggest that respondents confuse temp agency work with fixed-term contracts or even fail to understand the concept of temp agency work. In addition, it is shown that inconsistent respondents were less often interviewed face-to-face but filled out their questionnaires more often on their own.

In this paper, an easy-to-use adjustment procedure is proposed that filters out at least the obvious inconsistent responses. However, this is certainly not a comprehensive solution for the problem, as the resulting number of temp agency workers still differs significantly from official data. Therefore, it seems necessary to re-phrase the agency question again and to provide some additional information about the concept of temporary agency work in the questionnaires.

\section{References}

Adamy, W., 2010, Arbeitsmarktrisiken in der Leiharbeit, Wirtschaftsdienst, 9, p. 598-605

Brehmer, W.; Seifert, H., 2008, Sind atypische Beschäftigungsverhältnisse prekär? Eine empirische Analyse sozialer Risiken, in: Zeitschrift für Arbeitsmarktforschung, 4, p. 501-31

Statistik der Bundesagentur für Arbeit, 2011, Arbeitnehmerüberlassung, Leiharbeitnehmer und Verleihbetriebe im 2. Halbjahr 2010, Nürnberg, Berichtszeitraum 2. Halbjahr 2010 bzw. zum Stichtag 31. Dezember 2010

Dütsch, M., 2011, Wie prekär ist Zeitarbeit? Eine Analyse mit dem Matching-Ansatz, in: Zeitschrift für Arbeitsmarktforschung, 4, p. 299-318

Hohendanner, C., 2010, Unsichere Zeiten, unsichere Verträge?, IAB-Kurzbericht Nr. 14

Puch, K., 2008, Zeitarbeit - Ergebnisse des Mikrozensus 2006, in: StatMagazin, März, URL: [http://www.destatis.de/jetspeed/portal/cms/Sites/destatis/Internet/DE/Navigation/Publikation en/STATmagazin/Arbeitsmarkt2008_3,templateId=renderPrint.psml_nnn=true], 27.10 .2011

Sachverständigenrat zur Begutachtung der gesamtwirtschaftlichen Entwicklung (SVR), 2011, Verantwortung für Europa wahrnehmen, Jahresgutachten 2011/12, Wiesbaden 